\title{
Changing Policies for the Automotive Industry in an 'Old' Industrial Region: An Open Innovation Model for the UK West Midlands?
}

\author{
Stewart MacNeill ${ }^{*}$ and David Bailey
}

(appeared in International Journal of Automotive Technology and Management, 2010, Vol.10, No.2/3, pp.128 - 144)

\author{
Centre for Urban and Regional Studies, Birmingham Business School, Birmingham B5 2TT, \\ UK \\ Coventry University Business School, Priory Street, Coventry, CV1 5FB, UK. \\ E-mail: s.macneill@bham.ac.uk \\ E-mail: david.bailey@coventry.ac.uk \\ ${ }^{*}$ Corresponding author
}

\begin{abstract}
The manufacture of automobiles and components in the UK West Midlands reached its peak during the two decades after the Second World War. In the following four decades, despite the overall growth in world sales, there has been a steady decline both in the numbers of vehicles produced and overall employment as local industry found itself unable to cope with overseas competition brought about by the opening of world trade through GATT and then, latterly, by the UK's membership of the European Single Market. Over this same period a succession of both national and regional policy measures have been spectacularly unsuccessful. Initiatives such as the government supported merger of independent producers to form of the British Motor Corporation in the 1950s, the use of the planning laws to encourage green field development away from the region in the 1960s, the nationalisation of the (then) British Leyland in the 1970s, the support for FDI by Japanese manufacturers in the 1980s and the Rover-centric Accelerate project in the 1990s have all tended to mirror and/or exacerbate the problems of short-termism and poor practice. Since early 2000, regional policy has been under the stewardship of the local Regional Development Agency, Advantage West Midlands. Rather than simply seeking to preserve existing policy, the RDA has latterly adopted new policies to support niche manufacturing and high value engineering and to align the regional knowledge base with the search for sustainable solutions to environmental and congestion issues. The new strategy moves away from traditional support measures based on the needs of big companies or 'champions' and instead adopts a devolved approach centred on a mix of small and large businesses and high level research, and - arguably - towards an 'open innovation' approach. In this article we examine these new policy measures and their potential to create a new innovative and competitive environment in the region.
\end{abstract}


Keywords: Auto industry, regional innovation systems, clusters, open innovation, regional development agencies, industrial policy.

Biographical Notes: Stewart MacNeill is Lecturer in Economic Development at the Centre for Urban Regional Studies at the Birmingham Business School, UK. His research interests cover the knowledge economy, innovation, the automotive industry, the interface between public policy and business strategies, regional economic development and technology foresight. He recently coordinated the EU-funded EURODITE project.

Professor David Bailey works at Coventry University Business School, UK. He has written extensively on industrial and regional policy and globalisation, especially in relation to the auto industry. He was principal investigator on an Economic and Social Research Council (ESRC) project looking at the impact of the MG Rover closure and the policy response to this. Bailey has held visiting posts In Italy, the US, France and the Czech Republic.

\section{Introduction}

In the course of its history the automotive industry has on several occasions set the paradigms for analysing industrial organisation, including assembly line production (Ford), and - arguably - 'lean production' (Toyota).i' In the past four decades, further radical changes have affected the entire value chain, from manufacturers and suppliers to service providers and dealers (Chanaron 2004, MacNeill and Chanaron 2005; Womack et al 1990). The main drivers have been the pressures of cost recovery and intense competition which, together, have driven scale economies, the outsourcing of 'non-core' activities and the gradual inclusion of a range of high value electrical, electronic and communications components where cost recovery is more readily attained. In addition, increasing regulatory pressures (and consumer demands) - for example on the environmental front - have led to the development of new technological developments such as the search for more efficient powertrains as well as a drive for efficient alternative propulsion.

In contrast with expected 'life cycle' models of industry development, the 'crisis of cost recovery' has intensified over time (Bailey and MacNeill, 2008). As a result, large scale production over different models and brands using a platform sharing approach has been adopted to generate the cash for future model development. Simultaneously, major manufacturers are developing assembly operations in low cost locations such as Central and Eastern Europe, or the southern states of the US. The industry is now confronted with further major and profound challenges (Maxton and Wormald, 2005). The financial crisis has exposed the business model and financial position of most companies as fundamentally weak; profit margins are low and the need for scale efficiency has led to over-investment in 
production capacity (Bailey et al, 2008), now exacerbated by the global recession. During 2009 , compared to 2008 , both private and fleet sales have fallen in all major 'developed' markets. Even in the 'auto-boom' areas of Central and Eastern Europe, India and China the same picture is evident.

The industry is ill-equipped to face this economic crisis. Recently the CEO of FIAT, Sergio Marchionne, expressed doubts that all companies could 'go it alone' and proposed that the minimum scale for a volume producer will be around $5.5 \mathrm{~m}$ vehicles per annum suggesting a further round of consolidation and/or strategic alliances to share costs. Vehicle producers will seek more cost cutting and expect more parts to be made in low cost regions with 'knock-on' effects in the supply industry. This will have a further negative effect on companies and jobs with many smaller suppliers, who have little cash reserves, becoming particularly vulnerable. As liquidity runs short many will face bankruptcy - perhaps between 10 and 20 percent.ii

In addition, political and consumer pressures are forcing a re-assessment of the accepted thinking on vehicle construction, technology and marketing. Thus, there are, potentially at least, a number of major changes in the pipeline that may influence the industry's development over the next decade. For the policy community such changes present the challenge of maintaining support for production while adopting policies appropriate to a rapidly changing economic and political environment. Our case study focuses on the automotive industry in the UK West Midlands, one of the 'old' automotive regions in Europe where recent years have seen the decline of the region's once dominant volume production. We observe a parallel development towards a form of 'open innovation' model that may have wider applicability beyond the current recession. The paper proceeds as follows. Section 2 examines innovation challenges in the auto industry and the variations across innovation systems in different regional and corporate settings; section 3 details the auto industry in the UK and the West Midlands; section 4 moves on to look at the industrial and regional policy framework and how policy has developed to meet both the changing situation of the UK industry and the environmental challenge; section 5 then looks at possibilities for a shift towards an open innovation system where trust and reciprocity might replace the prevalent hierarchical model. Some conclusions round off the paper.

\section{Innovation Challenges in the Auto Industry}

Production is dominated by the vehicle makers, or OEMs, with the largest 10 of these accounting for some $75 \%$ of world output. These firms rest at the centre of a matrix of 
upstream supply (as oligopsonistic purchasers) and downstream distribution and sales (as oligopolistic sellers). In consequence they have controlled the industry's innovation model which for the most part is 'top down' - i.e. hierarchical - and proprietary with closed interfaces and few open areas where independents can easily plug in (Jürgens, Blöcker and MacNeill, 2008). Only in very limited cases are supplier brands apparent to consumers. As observed two decades ago by Pavitt, (1984) and more recently by authors such as Cooke et al (2007), in reference to the knowledge economy, the automotive sector is a mature industry, dominated by large companies and, therefore, not regarded to be at the cutting edge of innovation or economic growth. Thus, for the most part, innovation is incremental and process oriented. These features reflect the socio-economic maturity of the market, where companies are risk averse, and the need to extract maximum returns from production under the 'lean model' (Womack, et al 1990) of squeezing resources and continuous improvement (or cost cutting); the so-called 'QCD' (quality-cost-delivery) challenge. iv

Thus, the industry has tended to be conservative in its approach. Nevertheless the need for cost recovery has driven a great deal of technological change such as the inclusion of electronic control devices which have made vehicles more fuel efficient and improved both safety and reliability. However, the rise in oil prices, concerns over global warming and, more recently, the financial crisis have led governments and consumers to seek fuel economies and vehicles with lower emissions and higher levels of environmental sustainability, thereby presenting major challenges to the industry. The $\$ 50 \mathrm{bn}+$ of funds offered to support the US car makers through soft loans and Chapter 11 over 2008-2009 has been well publicised. Similar schemes to provide loan guarantees and loans have been developed across Europe, despite the strictures of State Aid provisions under the Single Market regime. Partly because of this, in most cases the 'aid' is tied to greater innovation and the green agenda. The UK industry Secretary Peter Mandelson has, for example, announced $€ 2$.3bn of loans and loan guarantees to the industry but has made it clear that funding will be directed towards new low carbon investment projects (Birmingham Post, 27th January 2009). At the same time, agreement has been reached between the European Commission and the European carmakers that the current voluntary target on $\mathrm{CO} 2$ emissions, of $120 \mathrm{gms} / \mathrm{km}$, should become a binding agreement for new cars of $130 \mathrm{gms} / \mathrm{km}$ by 2015. In the US President Obama has also warned manufactures about their continued production of 'gas-guzzlers'. It is thus possible that in the next decade demands for more radical change will challenge the traditional car making paradigms of high volumes, steel bodies, and ICE drives. 
A number of technological routes to emissions reduction are currently being explored by the OEMs (large and small), major suppliers and R\&D organisations. The different possibilities are explored in the UK Report on Low Carbon Vehicles (King, 2008), which distinguishes between short and long term changes to both fuels and vehicle technologies. The former are largely based on the current paradigms and involve the adoption of technologies such as stop-start, variable valve timing, turbo-charging and weight reduction. Fuel changes include the use of liquid petroleum gas (LPG) compressed natural gas (CNG) and bio-fuels made from crops either used directly (notably in Brazil, with the use of ethanol made from sugar cane) or as blends with petrol or diesel. In Europe the Bio-fuels Directive (2003) requires that, by $2010,5.75 \%$ of fuel for road traffic is from renewable sources. More radical change includes full hybrid vehicles where a conventional gasoline or diesel engine is supplemented by electric motors powered by batteries charged by the conventional engine and through regenerative braking. The new GM 'Volt' (Opel Ampera in Europe) provides a 'plug-in' variant to the hybrid concept where batteries can be charged from mains electricity and/or a conventional engine but the drive to the wheels is 'all electric'. An alternative is the 'mild' hybrid which employs a starter-generator device in the driveline to utilise regenerative braking energy.

Another 'conventional' way to reduce fuel use is by weight reduction through the use of lightweight $\mathrm{Al} / \mathrm{Mg}$ alloys and increased use of plastics. More radical or long term changes include a possible move to full electric vehicles where the drive is entirely by electric motors powered by batteries. Even more radical is to switch to using hydrogen as the main fuel source. However, despite its potential environmental benefits, there are major challenges associated with the production, distribution and storage of hydrogen. It is also clear that the total life cycle emissions (LCEs) may be higher or lower than conventional petrol and diesel depending on the mode of production of hydrogen.

\section{Innovation Models in the Auto Industry}

Such innovations, of course, cannot take place in isolation. That innovation is a systemic process, based on a series of networked interactions and institutional learning, stems from the writings of authors such as Lundvall (1992), Nelson (1993), and Nelson and Rosenberg (1993). That innovation systems could be characterised at regional level was first proposed by Phil Cooke (1992). Subsequent writings have further defined the concept (see Cooke, 1998). Thus national and regional innovation systems, related to the automotive industry, can be divided between those closely connected to company headquarters where new knowledge is produced, and innovation is developed, and those in 'branch plant' countries or 
regions that are primarily users, rather than producers, of knowledge and therefore innovation followers). ${ }^{\vee}$ In the latter the innovation system is geared to incremental process improvement with networks aimed at cost reduction. New, radical, change is controlled by gatekeepers outside the region, or the country, in question. Here relationships between the players tend to be old fashioned and adversarial and based on asymmetries of power and knowledge (Bathelt andTaylor, 2002). Innovation systems tend to be reactive and reflect a production system being for the most part closed, proprietary and dominated by a small number of large transnational companies. By contrast systems that are more pro active are characterised by high levels of trust and reciprocity. Cooke (1998) distinguishes three types of innovation system as 'dirigiste', where external control is exerted by industries or governance organisations, those that are 'networked' amongst different levels of governance and funding sources and those that function from the 'bottom up' or 'grassroots' level. With the changes described above we might expect to see the divisions between innovation systems reinforced with the more radical developments taking place in those areas where the major firms have their headquarters and only incremental developments occurring in the follower regions. Furthermore, Chesborough and Teece (1996) differentiate 'systemic' from 'autonomous' innovation, and in this context they discuss alternative forms of organisation within innovating sectors, a point which we pick up again in section 5 below in relation to the concept of 'open innovation'.

However, the changes described above not only affect the vehicle paradigms but they also open markets to new players with particular expertise in these new technologies. Two examples (amongst many) are Tesla Motors of Silicon Valley, California and the US-Indian electric car manufacturer Reva whose G-Wiz electric car is marketed in Europe, USA and Japan. The former has signed an agreement with Lotus for manufacturing in the UK and recently Daimler purchased a 10\% stake in the company in order to integrate Tesla's Li-ion battery technology into the electric SMART that has a drive developed, manufactured and fitted by the UK firm Zytec. These examples illustrate how new players can develop innovations but may need to enter into ventures with established assemblers to bring them to the wider market. Such ventures bring change to the territorial organisation of the industry since, as in some of the examples above, the players may be located outside 'traditional' areas. In addition the new actors are developing research based knowledge with a largely codified content. However, this needs to be allied to traditional knowledge of the major companies and linked to their networks of upstream supply and downstream logistics and marketing. At this stage knowledge networks may be distant. 
In a later work Cooke (2008) distinguishes between what he terms the 'industrial paradigm' of policy based upon sectors (or clusters), closed innovation, closed sources and disciplinary science and a new 'knowledge-based paradigm' of networks, open sources and interdisciplinary science. Policy in the former circumstances has tended to be geared towards support for efficiency savings through business support mechanisms such as subsidised management consultancy or training. Such policy measures have often followed the expressed 'needs' of the major OEMs and suppliers in their quest to reduce costs. These companies have been adept at playing countries, regions and plants against each other within their own 'internal bidding' procedures (Bailey and Cowling, 2006). However, as the industry changes to deal with the political and economic constraints of the 'post-crisis' period, there is a challenge for policy to be geared to the transition.

\section{The Auto Industry in the UK and West Midlands}

The motor industry continues to be an important part of the UK economy. In 2007, there were more than 3000 businesses, a total manufacturing workforce of 180,000 and overall GVA in excess of $€ 11,000$ m (BERR, 2007). ${ }^{\text {vi }} A$ further 552,000 people were recorded as employed in related trades such as retailing and fuel. The industry trends of globalisation and consolidation are well illustrated by the UK experience where the open nature of the economy has enabled and encouraged these trends more than in other European countries. Government policies, and flexible labour laws, have encouraged inward investment by Toyota, Nissan, Honda and BMW. The UK has also become a major engine producer with investments by Ford (Wales, Dagenham), Toyota (NW England) and BMW (West Midlands). Although overseas ownership makes the UK industry vulnerable to global decisions on cost cutting, and the re-location of production, there are a number of plus points. It has brought major investment, and the innovative capacity of UK engineering is still strong. In addition, the UK has a major concentration of high value automotive design and engineering businesses. It is also the centre of a major motor sport cluster, with most of the major teams in Formula 1 being located in 'Motor Sport Valley' (Pinch and Hendry, 1999), an area stretching across the southern half of England. The 'Valley' has around 4000 businesses, with a turnover of approximately $€ 7.5$ billion, employs approximately 38,500 people (including 25,000 engineers) and is a global centre for the production of performance cars and a wide range of other products, services and facilities. (MIA, 2009)

\section{The West Midlands Region}


The West midlands region is located in the central area of England, as shown in Figure 1, and covers an area of around 13,000 sq km from Stoke-on-Trent in the north to Hereford and Evesham in the South. It comprises two major conurbations of Birmingham/ the "Black Country' together with Coventry and Solihull in the central area and the North Staffordshire conurbation around Stoke on Trent plus the rural counties of Shropshire, Staffordshire, Warwickshire and Worcestershire.

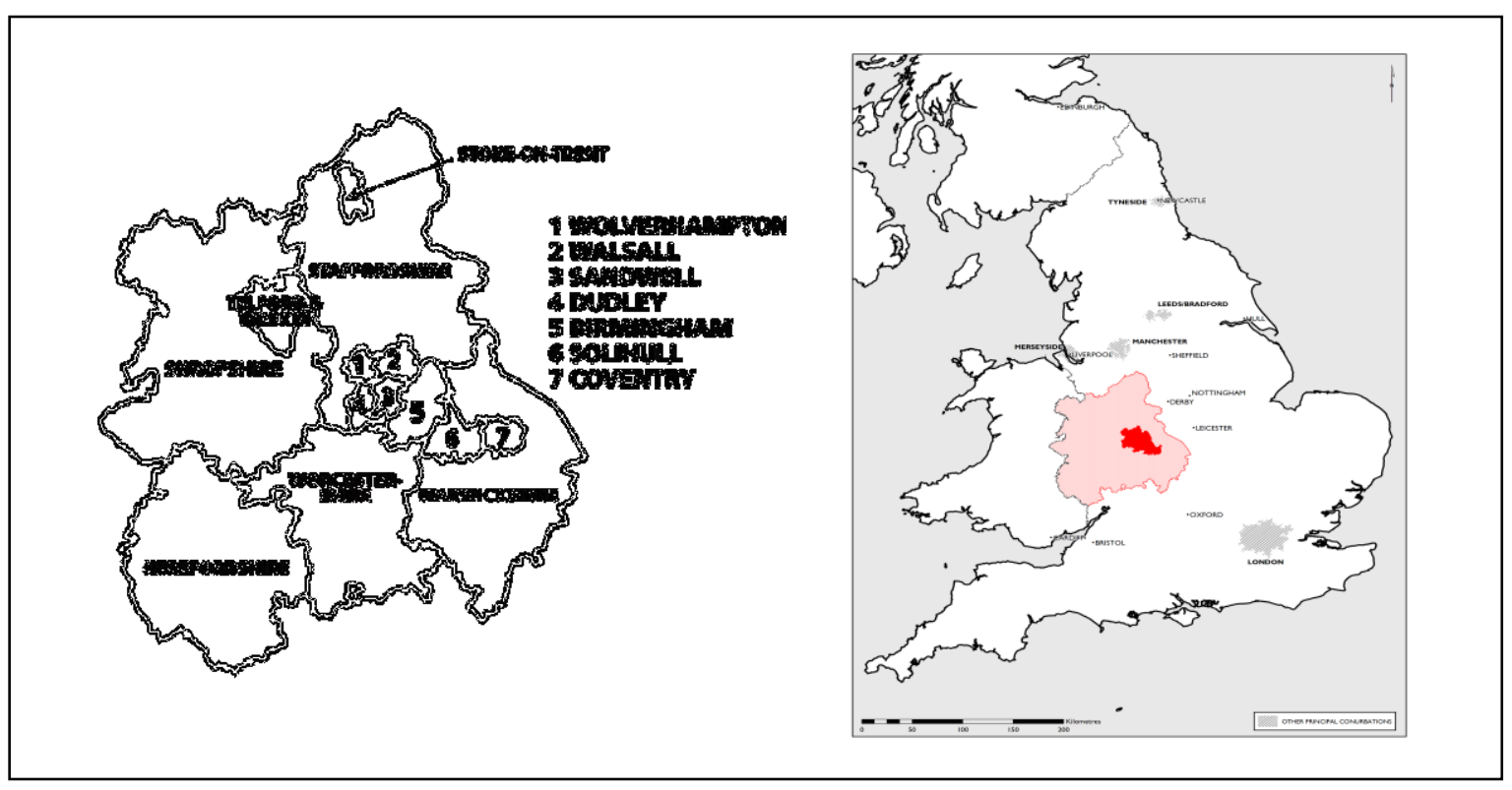

\section{Figure 1: The West Midlands Region}

The region has around 5.3 million inhabitants of which more than $65 \%$ live in the main urban areas. The population increased slowly in the three decades from 1971 with a combination of net 'internal' (intra-national) outflow and net 'international' inflow reflected in the increasing diversity of the population. The region was the birthplace of the industrial revolution and became famous for manufacturing a wide variety of metal, leather, ceramics and glass products. Restructuring of these industries has reduced the number working in these sectors, but manufacturing still accounts for $21 \%$ of the region's GVA and $19 \%$ of employment. Approximately 2.3 million people work in the region in approximately 211,000 business sites - of which 10,300 are engaged in manufacturing. The total regional GVA in 2004 was $€ 84.9$ billion out of a UK total of $€ 1,104.4$ billion. This represents a figure for GVA per head of $€ 16,857$ per annum which is $91 \%$ of the UK average. Current regional unemployment on an ILO basis is $10.3 \%$ - above the national average of $7.8 \%$ (ONS, 2009), after rising rapidly during the recent recession.

The region is one of the long standing areas of global motor industry production. The heyday of production was after World War 2 but, in the following decades, with open trade rules and 
globalisation, the industry declined. A popular view is that local companies could not compete in global arenas as a result of insufficient investment, poor labour relations, poor quality and cost control, and - critically - the lack of a supportive industrial policy on the part of the government. ${ }^{\text {vii }}$ Despite a number of foreign takeovers the industry's fortunes continued to decline. The recent closures of the MG-Rover and Peugeot plants effectively ended volume manufacture in the region. Most recently Jaguar land Rover has announced a further plant closure, which is planned for the middle of the next decade. In parallel there has been a decline in activities by the major suppliers. Bosch recently closed its automotive lighting plant in the north of the region and TRW its electric power steering plant in Birmingham. These changes have affected employment in the sector with a 34\% reduction in the 10 years from 1997 to 2007 (ONS, 2008).

In parallel to the decline in volume manufacture the there has been a relative growth of higher value or specialist production where profit margins are greater and which can (therefore) be more sustainable in a high wage cost economy. Companies involved range from relatively large producers, such as Jaguar Land Rover, through medium sized companies such as Aston Martin to small scale producers such as the sports car producer, Morgan Motors. Many of these businesses have developed out of the motor sports sector. For example, the electric car developer Zytec is best known for racing, and developed its expertise in electric vehicles from producing a high performance electric version of the Lotus Elise. Alongside this niche manufacturing there is a growing (and relatively new) base in engineering design and development services ranging from major international businesses like TRW, Ricardo and MIRA to small and medium sized companies like Zytec, Prodrive, and others. Like the SMEs in the volume sector they are also a legacy of past volume based manufacturing but differ in two important respects. Firstly, they are largely vehicle (product) oriented rather than manufacturing (process) oriented and, secondly, they are in a high value segment of the supply matrix. These KIBS (Knowledge Intensive Business Services) have largely developed as a result of the vehicle makers' trend towards outsourcing to experts to save on the sunk costs of research and development departments (Antonelli, 2005) although the recent decision by the Chinese firm Shanghai Auto to take its West Midlands based '20/20' joint venture with Ricardo in-house contrasts with this trend. In particular a number of companies are working in areas connected to 'green technologies' including indirect technologies such as telematics systems through to direct low carbon vehicle technologies such as hybrid or electric drives. Research activity has also been stimulated and supported by public investment in the region's universities such as Warwick (lightweight 
construction), Birmingham (hydrogen fuel cells) and City of Birmingham (ICE engines), as well as the demonstration testing of electric vehicles (Birmingham and Coventry).

\section{The West Midlands' Innovation System}

As would be expected for a region with significant manufacturing, the West Midlands scores reasonably well on the European Innovation Scoreboard (INNO Metrics, 2007) and stands as Europe's $42^{\text {nd }}$ most innovative region, despite a history of a long 'tail' of firms with poor innovative performance (De Propris, 2000). However, the significant level of overseas ownership in the mass vehicle sector has resulted in strategic decision-making being carried out elsewhere. Thus high level technical knowledge inputs to the larger businesses comes from outside the region. Even the most embedded companies, such as the top tier suppliers GKN and TRW, have transferred much of their advanced R\&D work to Germany in order to be closer to major OEMs and the centre of gravity of automotive technologies. It is, therefore, clear that the region has missed a generation of investment in many modern technologies. As a result, local knowledge networks are mostly concerned with manufacturing and with process or incremental innovation. The innovation system therefore fits Cooke's (op cit) dirigiste model dominated by outside interests and with little in the way of unique or 'sticky' knowledge (Malmberg and Maskell, 1997).

For the KIBS and niche sector, however, the knowledge balance is rather different. Here the region is clearly a producer of knowledge since the companies are either knowledge producers per se because they are in the KIBS sector or are able to control their own knowledge flows by virtue of local ownership. Amongst these niche and specialist companies, a significant group is the 'Niche Vehicle Network'. This comprises some 25 specialist vehicle manufacturers and engineering services companies, most of which have their origins in motor-sport, specialist vehicle manufacture, engineering KIBS or high technology parts production. The participants are developing particular technologies but are too small to be able to market these in whole vehicles for general sale. Instead the objective is to develop and prototype these for sale or licence to the major companies. Inevitably these will be outside the region or, at least, will be controlled by companies outside the region. Examples include Zytec's prototyping of the electric drive train for the SMART and a joint venture with Daimler, as well as the firm's development of electric delivery vans and a prototype fuel cell van being tested by the University of Birmingham as part of the Science

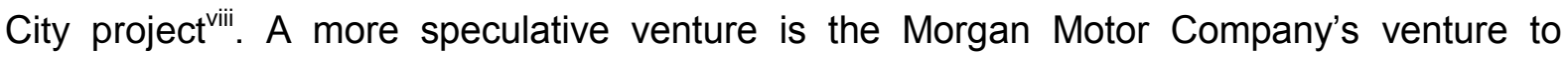
develop a hybrid and then a fuel cell powered sports car. One firm which has developed end-vehicles is the Coventry-based electric commercial vehicle manufacturer Modec, which 
through its joint venture with the US firm Navistar, is set to benefit indirectly from the Obama government's support for green vehicle technologies.

\section{The European and Regional Policy Framework}

At the European level three major policy areas impact on the industry. The first is the macroeconomics of free trade inside and outside the EU. The second involves common standards (regulation) on emissions (EURO IV, EURO V, late 2009 and EURO VI, 2014) and safety (EURO NCAP tests) which are compulsory in all Member States. Another important area is re-cycling and the End-of-Life Vehicle Directive which came into force at the beginning of 2007.

At the national (UK) level policies have been, for the most part, non-interventionist and concentrated on improving the business environment (Bailey and Driffield, 1007). For example, labour laws have remained 'flexible' in order to attract and retain inward investment. Thus, while indigenous companies have declined, new inward foreign direct investment, both green-field and acquisition, have meant that foreign owned transnational firms have maintained 'a car industry in the UK' (as opposed to a UK car industry). The noninterventionist approach has been shelved for the present with the Automotive Assistance Package (AAP) with the promise of support to Vauxhall (Opel) and the introduction of a scrappage scheme in common with other Member States. ${ }^{i x}$ In the manufacturing arena, national policy has shifted away from sector-specific support to general support for all manufacturing sectors (i.e. from vertical to horizontal industrial policy measures). Much of the automotive specific effort has been directed through the Foresight Vehicle Programme which has sought to fund collaboration amongst companies and research organisations in order to address forecasts for 'future vehicle capabilities' as outlined on a technology road map. Reduction of life cycle emissions (LCE) has been a major policy imperative. One example is the CENEX initiative to promote UK market development and competitiveness in low carbon and fuel cell technologies for transport applications. CENEX, which was established with support from the then Department for Business, Enterprise and Regulatory Reform (BERR) seeks to stimulate market transformation and networking amongst providers and end users including the Low Carbon Vehicle Procurement Programme and the Low Carbon and Fuel Cell Technology Knowledge Transfer Network. 
The King Report (2008) concludes that considerable reductions in CO2 emissions (up to $30 \%$ ) could be achieved in the short term by enhancements to conventional vehicle systems whereas in the medium term advances in hybrid and battery technologies could bring a $50 \%$ reduction in $\mathrm{CO} 2$ emissions per kilometre by 2030. A second report, that will guide future UK policy, is the Automotive Industry Growth Team Report (BERR, 2009). This makes a number of recommendations to improve the business environment, to stimulate further inward investment, to improve the market conditions for low carbon vehicles, to coordinate $R \& D$ efforts and to set up small scale demonstrator fleets as well as continuing the policy of improving supply chain efficiency.

At the regional level policy is implemented by the RDA (Advantage West Midlands) through successive iterations of the Regional Economic Strategy (RES). While the strategic direction has remained the same, the method of approach has altered significantly. The first RES 'Creating Advantage' (AWM, 1999) adopted a sectoral approach for the delivery of its priorities, whilst the second focused on ten priority 'clusters' including transport technologies The current RES 'Connecting to Success', (AWM, 2008), emphasises cross cluster activities and the benefits of networking and linkages across the different priority areas. ${ }^{x}$ Nevertheless, in spite of changes in the method of delivery, there is a clear agenda in the Region's economic strategies to reduce its dependence on low value added industries while concentrating on areas that offer growth potential (Donnelly et al., 2005; Bailey and De Propris, 2009).

As might be expected, national policies have been highly influential. Thus the RDA's strategy is aligned with the national strategy to support low carbon vehicles and intelligent traffic systems. The most recent substantive policy statement from the Agency, the 'Automotive Strategy 2008-2011' (AWM, 2007) affirms the RDA's support for manufacturing process improvement but also emphasises the need to improve technologies, raise skill levels and support the niche vehicle sector including that part of the 'Motor Sport Valley' cluster located in the region which supports some 2,400 local jobs. Not surprisingly, much of the RDA's strategy is aligned with the national strategy to support low carbon and intelligent traffic systems. Particular priorities include Low Emission Vehicles, Intelligent Transportation Systems (ITS) and the Niche Vehicle Cluster Growth programme. In addition policy has supported technology development through funding to local universities. An example is the investment of some $€ 20 \mathrm{~m}$ in the Premium Automotive Research and Development (PARD) programme based at Warwick University Manufacturing Group to develop new vehicle and environmental technologies in the region. 


\section{Shifts in Policy Support}

Overall, businesses and policy makers in the West Midlands region face a number of issues if the sector is to be retained and developed. Employment costs are high; outsourcing and the flight from high wages and employment legislation in more developed countries will no doubt continue (Jürgens and Krzywdzinski, 2008). Also, the UK's flexible labour markets make shedding labour relatively easy (Bailey and Cowling, 2006). The recent economic crisis, with the global drop in sales and production, has brought additional difficulties. In addition, the legacy of the previous age of volume manufacturing is a supply base still geared to volume and a knowledge base where the main expertise lies in traditional mechanical (physics based) technologies which represent a declining proportion of the value of new vehicles and, given the cost pressures of the 'lean manufacturing' paradigm, provide small profit margins.

It is also clear that the environmental concerns of policy makers and the public will impact at regional level. For example, Government support for Jaguar Land Rover during the current crisis is focused on the development of low carbon technologies (The Birmingham Post, 2009). Thus regional policy makers and companies in the sector seek a 'reinvention' as a base for new technologies, particularly related to the emerging 'green agenda', and a possible new vehicle manufacturing paradigm. Such a change could be a portent of a new image (or brand) for the regional automotive industry where niche, high value vehicles, advanced engineering, green technology and motor sport ${ }^{\mathrm{xi}}$ replaces high volume vehicle assembly and a supply sector based largely upon low value 'metal bashing'. These changes are consistent with the 'worlds of production model' (Storper and Salais, 1997). However, the social implications are significant in employment terms. Not only will overall numbers continue to fall, as the existing supply matrix continues to shrink, the traditional networks based on a strong tacit understanding of the 'old' automotive paradigm cannot immediately evolve into 'new' high technology networks with higher inputs of codified (research based) knowledge. This evolution puts further pressure on a workforce with 'traditional' skills and creates new imperatives for policy makers.

Thus from the preceding analysis we can identify a shift in local knowledge requirements (a regional knowledge dynamic), as the local automotive sector moves away from volume production, and the traditional knowledge of manufacturing (process) technologies, towards a new higher technology knowledge base in vehicle (product) technologies and low carbon (green) technologies. However, the new paradigms described here may shrink the supply 
matrix given the higher value added of the technologies and processes involved - i.e., a move away from largely cost-based competition. Linkages to other regions in the UK and other European countries are essential for such components as electric motors, electronic control units (ECUs) and fuel cell technologies.

In the West Midlands, some 25 niche and specialist businesses have formed the Niche Vehicle Network and announced a new research programme (with a small amount of public financing support of $€ 2.7 \mathrm{~m}$ from the RDA) in late 2008 . The programme is closely aligned with national as well as regional policies and is intended to build a specialist knowledge base with: a new product development capability for niche vehicle manufacturers; joint ventures into overseas markets; an expansion of the skills base, with more graduate recruitment and an up-skilling of the wider workforce, and the promotion of the region as an area of high innovation. The network's research and development themes include: improved fuel efficiency and carbon reduction (electric vehicles, hybrid technologies, reducing emissions from existing petrol engines, alternate fuels including bio-fuels, aerodynamics); weight reduction and an improved capacity to recycle (aluminium chassis technology, vehicle interior plastics, composite/plastic body panels/structures); and vehicle safety (advanced vehicle dynamics, vehicle telematics/electronics systems, and crashworthiness).

Links by companies in the Niche Vehicle Network include those to Bosch (ECUs), BMW (IC engines), Johnson-Matthey (fuel cells) and the engineering departments at Oxford and Cranfield Universities (hybrid technologies). Thus, new technical knowledge is derived from outside the region. However, the policy objective is that it can be anchored in the region, through development, manufacture and testing.

\section{Towards an Open Innovation Model?}

As a consequence of the trends described above, regional actors are confronted with managing a major transition. The former volume producers (MG Rover, Peugeot) have closed along with some significant suppliers. However, much of the broad supply matrix is still geared to this former volume production and is seeking new customers and a diversified product range. Until recently most local policy spending was geared to the retention of this segment of the industry but over the last five years, or so, a policy shift has occurred. Now, as well as concentrating on process improvement, private and public actors are trying to develop new generations of technology - such as low carbon vehicles and telematics. The current crisis, and the political pressures that have followed, may, arguably, be giving further 
impetus to these efforts with the promotion of more environmentally friendly vehicles and more sustainable business models.

The Niche Vehicle Network is one manifestation of this new direction. Its attempts to develop new technologies through a network of small and medium sized companies can be compared to the open innovation model (Chesbrough, 2003) as illustrated in Figure 2 below. As Chesbrough has noted, "open innovation is a paradigm that assumes that firms can and should use external ideas as well as internal ideas, and internal and external paths to market, as the firms look to advance their technology" (ibid). In this sense, the boundaries between firms and their 'external' environment become more permeable, with an easier flow of innovations in and out of firms. In essence, where knowledge is widely distributed, firms cannot just rely on their own innovative activities: they can and should access patents and processes from other firms, whislt also allowing their own unused innovations to be utilised externally through licensing, spin-offs and joint ventures (Chesbrough, 2003a). Chesborough's earlier (1996) work also looked at the appropriate organisational form required where innovations could be autonomous or systemic, and whether the capabilities firms need exist internally or externally.

Trust is a strong element of relations in the Niche Vehicle Network. The companies are of similar scale and have complementary skills. They thus feel able to be open and share ideas. As such they fit more closely the third of Tully and Berkeley's (2004) cooperation groupings - companies that cooperate in a Granovetter-type 'social network model' and contrasts with adversarial interactions prevalent in the industry. An open knowledge flow is also conducive to innovation as observed by Cooke (2005) and Antonelli, (2005). 


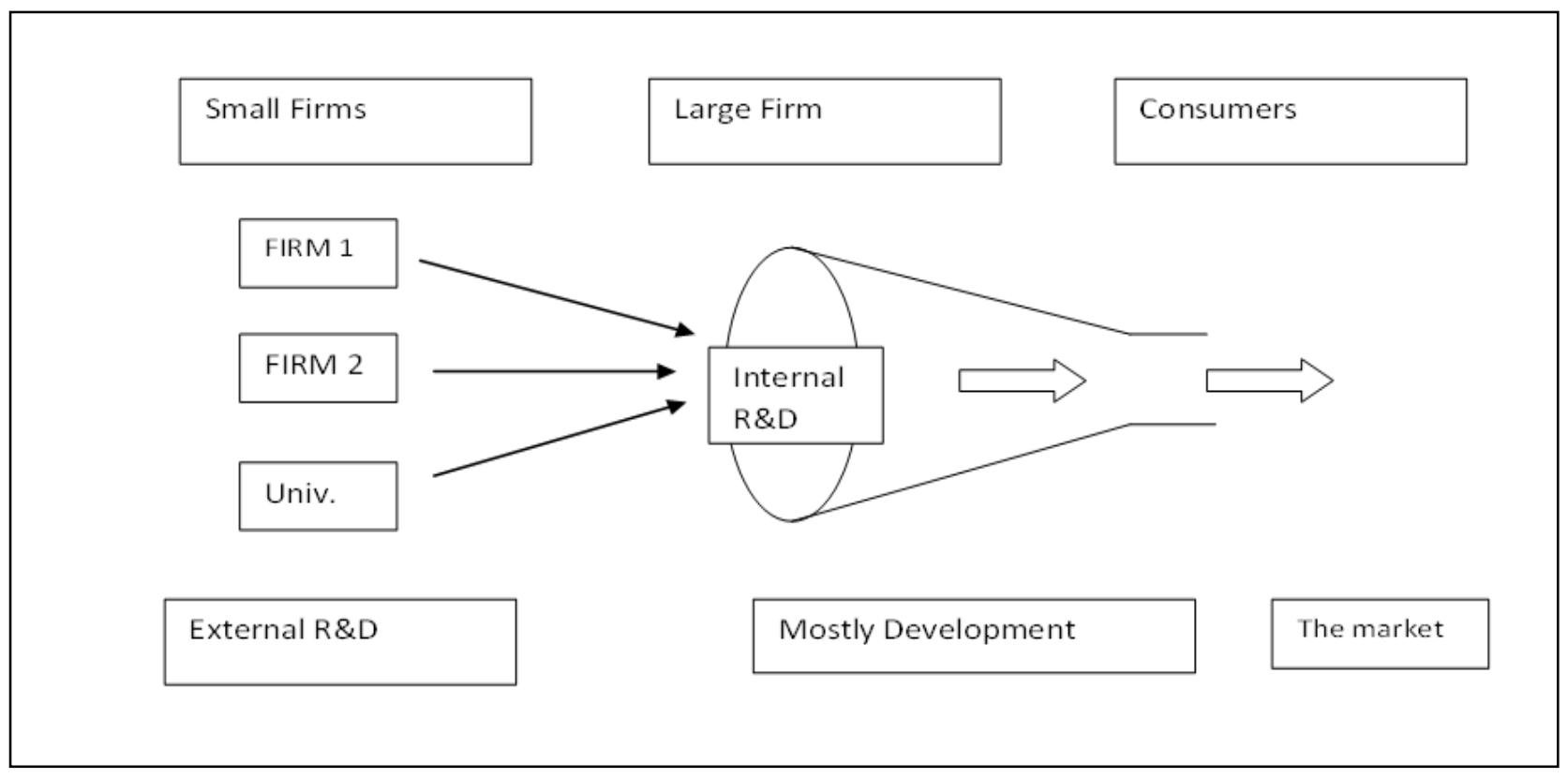

Figure 2: An Open Innovation System (after Chesborough 2003)

Of course the network members, and the region itself, is competing with the major German, Japanese and US car makers and suppliers and such changes should not be taken as portents of a completely different geography of automotive manufacture. However, if the open innovation model, described above, represents a significant way in which regional players can gain a foothold in new automotive technologies then future policies might usefully incorporate an explicit target of open networking amongst diverse players to stimulate combinatorial knowledge dynamics. ${ }^{\text {xii }}$ However, quite how the policy then needs to change is a moot point. 'Open Innovation' (OI) may itself be partly driven by certain dimensions of policy, whilst simultaneously being constrained by others (for example, some aspects of Ol may be seen as anticompetitive). Of course, innovation policy has been evolving over time, and policymakers are already examining changing innovation issues and dynamics (including the role of $\mathrm{Ol}$ ) for innovation policy and related areas such cluster policies, support for SMEs, education, skills and more (see de Jong Jeroen et al, 2008, for policy implications arising from the emergence of Ol).

In this regard, policy needs to recognise the technological paradigm shifts taking place and adapt accordingly. An interesting analogy is with technology policy in the US. Here, there has been the use of a hidden but de facto industrial policy via the Pentagon and other areas of government in terms of the procurement and stimulation of high-technology products over many years, including computers, aerospace and semi-conductors (Geroski, 1990) and more recently dual-use flat-screen technologies (US Congress, 1995). As Geroski notes, in the case of the computer industry, such government action "almost single handedly brought 
into being what has now become an enormous commercial market". Of particular relevance here, this de facto industrial policy of targeting new technologies with widespread civilian spillovers has included the use of 'second sourcing' to deliberately stimulate a diffuse, competitive industry, rather than simply placing orders with giant firms (Geroski, 1990). This would seem key in the Ol approach; stimulating and maintaining a range of diverse actors with diffused strategic decision making. To what extent large firms outside the region still control the direction of innovative activities and how far they can control smaller innovative firms is also a key question for policy in attempting to stimulate an OI approach.

\section{Conclusions}

The traditional base of low to medium technology manufacturing in the West Midlands region has seen the development of a Regional Innovation System (RIS) dominated by external influences and geared to incremental process innovation. However, the West Midlands Region's Economic Strategy (AWM, 2007) makes clear the intention to reduce the region's dependence on low value added industries and to concentrate on areas that offer growth potential. Economic actors in the region are thus seeking to re-invent the region as a leader rather than a follower of technology.

Until very recently, regional policy towards the automotive sector was geared to the topdown influences of the prevalent lean manufacturing paradigms, and the short-term needs of a small number of large companies dominated the agenda (Bailey and MacNeill, 2008). However, the latest policy for the sector seeks to adapt policy to the changing regional circumstances of the industry and the demise of volume car production. The RDA's support for the Niche Vehicle Network seems to be shifting at least towards an open innovation model, or at least an innovation system with Ol elements.

Such a model may be a portent of a general trend as the industry globally struggles to adapt to the changing political economic circumstances in which the existing production paradigms are being questioned by politicians and the public alike. Such models are already prevalent in other industries such as pharmaceuticals, and may ultimately replace the closed, proprietary and cumulative knowledge dynamics currently prevalent. That is not to say that the vehicle makers will no longer control the supply matrix through their ownership of brands and direct interaction with vehicle purchasers. There are indeed limits to 'openness'. It is also clear that conventional production modes will persist for some years to come - because of scale, resources, and the 'lock in' of the existing technological paradigm. 
Yet times of economic uncertainty and recession have been argued to create opportunities for leaps in innovation and technological break-throughs as the scramble for survival triggers new ideas and creates new forerunners. Indeed processes of 'creative destruction' (Schumpeter, 1943) can redesign the map of competitors' strengths and weaknesses. If there is to be such a change, the model emerging in the West Midlands and other locations is worthy of examination. Small companies can often be more innovative than major multinationals. It is notable in this context that Daimler has decided to work with the West Midlands based company Zytec for electric vehicle development. The implications for policy arising from a possible shift towards an OI approach also need further examination. Here we have highlighted just one aspect of policy - the need to foster a diverse range of actors with diffused strategic decision-making, in contrast with the 'top down' and hierarchical nature of the 'old model'. Assuming that an $\mathrm{Ol}$ approach is possible in a regionally based innovation system, further research on the policy implications of such an approach is called for.

\section{References}

Advantage West Midlands (1999) Creating Advantage. The West Midlands Economic Strategy. AWM, Birmingham.

Advantage West Midlands (AWM) 2006 'West Midlands Economic Strategy (WMES) Review 2006-2007'.

Advantage West Midlands (2007) Automotive Cluster: three Year Plan, 2008-2011. AWM, Birmingham.

Advantage West Midlands (2008) Connecting to Success: West Midlands Economic Strategy. AWM, Birmingham

Antonelli, C. (2005) The economics of University: Measuring science in Italy. Comparing universities, positions, and disciplines. EURODITE Paper, available at:

www.eurodite.bham.ac.uk/Papers/WP2d/Cristiano2.doc

Bailey, D. \& Cowling, K. (2006) The Lesson Peugeot has taught Britain, Parliamentary Brief, June 2006.

Bailey, D and De Propris, L. (2009) Towards a Knowledge-Intensive, Green Manufacturing Future, in Hornsey, R., Howarth, S., Morton, P., Nicholls, O. And Paskins, R. Ed.s, West Midlands: Fit for the Future? Positioning the Region for Economic Recovery. Birmingham: West Midlands Regional Observatory.

Bailey, D. and Driffield, N. (2007) Industrial Policy, FDI and Employment: Still 'Missing a Strategy', Journal of Industry, Competition and Trade, Vol.7, Iss.2, 189-211.

Bailey, D Kobayashi, S and MacNeill, S (2008) "Rover and Out". Globalisation: The West Midlands Auto Cluster and the end of MG-Rover., Policy Studies, 29, 3, 267-280

Bailey D. and MacNeill S. (2008) The Rover Task Force: Case Study in Proactive and Reactive Policy Intervention? Regional Science Policy and Practice, 1, 1

Bathelt H, Taylor M, (2002), Clusters, power and place: inequality and local growth in time space Geografiska Annaler B, 84, 93 - 109.

BERR (2009) The Future of the Automotive Industry in the UK. Dept. for business, Enterprise and Regulatory Reform, London 
Birmingham Economic Information Centre (BEIC) (2005) 'Birmingham Economic Review and Prospects 2005', Birmingham: BEIC.

Birmingham Post. (2009) Business leaders welcome motor industry aid package, 27/01/09

Brown, J., Barber, A., Chapain, C, Gibney, J., Lutz, J., Murie, A. (2008) Understanding the attractiveness of Birmingham and the West Midlands Region for creative knowledge firms. AMIDSt: Amsterdam.

Cantwell, J. and lammarino, S. (1998). MNCs, Technological Innovation and Regional Systems in the EU: Some Evidence in the Italian Case, International Journal of the Economics of Business, Vol.5, No.3.

Cantwell, J and lammarino, S. (2000). Multinational Corporations and the Location of Technological Innovation in the UK Regions, Regional Studies, Vol.34, Iss.4.

Chanaron, J.J. (2004) Relationships between the core and the periphery of the European automotive system, International Journal of Automotive Technology and Management. Vol 4, 2/3, 198-222

Chesbrough, H.W. (2003). Open Innovation: The New Imperative for Creating and Profiting from Technology. Harvard Business School Press, Cambridge, MA

Chesbrough, H.W. (2003a). The era of open innovation. MIT Sloan Management Review, 44 (3), 35-41Chesborough H.W. and Teece, D.J. (1996) When is Virtual Virtous? Organising for Innovation. Harvard Business Review (74)1, 65-73.

Coates, D. (1996) The Question of UK Decline: the Economy, State and Society, Hertfordshire: Harvester Wheatsheaf

Coffey, D. (2006) The Myth of Japanese Efficiency. The World Car Industry in a Globalising Age. Cheltenham: Edward Elgar.

Coffey, D. and Thornley, C. (2009) Globalization and the Varieties of Capitalism: New Labour, Economic Policy and the Abject State', Basingstoke and New York: Palgrave MacMillan

Cooke, P (1992) Regional innovation Systems: Competitive Regulation in the New Europe. Geoform, 33, 365-382

Cooke, P (1998) Regional innovation Systems: Introduction. In H-J Braczyk, P Cooke and M Heidenreich (Eds.) Regional innovation Systems. UCL press, London.

Cooke, P. (2005) Regionally asymmetric knowledge capabilities and open innovation: Exploring 'Globalisation 2'-A new model of industry organisation, Research Policy, Vol.34, Iss.8, 1128-1149.

Cooke, P (2008) Co-evolutionary Transition Models. Industrial Economy to Knowledge Economy. EURODITE working Paper. CURS, University of Birmingham, UK

Cooke, P, de Laurentis, C, Tödling, F and Trippl, M. (2007) Regional Knowledge Economies: Markets, Clusters and Innovation. Elgar, London

Cowling, K. (1986) 'The internationalization of production and de-industrialization', in A. Amin and J. Goddard (eds) Technological Change, Industrial Restructuring and Regional Development, London: Allen \& Unwin, pp23-40.

de Jong Jeroen P.J. Vanhaverbeke, W. Kalvet, T. and Chesbrough, H. (2008) Policies for Open Innovation: Theory, Framework and Cases, Research project funded by VISION Era-Net, Helsinki, Finland.

De Propris, L. (2000) Innovation and Inter-Firm Cooperation: the Case of the West Midlands, Economics of Innovation and New Technology, Vol.9.

Donnelly, T., Barnes, S. and D. Morris (2005) 'Restructuring the Automotive Industry in the English West Midlands', Local Economy, 20:3, 249-265.

Geroski, P. 1990. Encouraging Investment in Science and Technology, in K Cowling and $\mathrm{R}$ Sugden, ed.s, A New Economic Policy for Britain. Manchester: Manchester University Press.

INNO Metrics (2007), European Innovation Scoreboard 2006. Available at http://www.proinno-europe.eu/doc/EIS2006_final.pdf

Jürgens, U, Blöcker, A and MacNeill, S(2008). The Automotive Sector: Knowledge Stocks and Flows. EURODITE Working Paper. Available at: 
http://www.eurodite.bham.ac.uk/partners/WorkPapers/WP3/WP3i/Automotive final.pdf

Jürgens U and Krzywdzinski M, (2008) Relocation and East-West Competition: The Case of the European Motor Industry. International Journal of Automotive Technology and Management. Vol 8, 2, 145-169

King, J. (2008) The King Review of Low Carbon Cars. HM Treasury, London

Lundvall, B-A. (Ed) (1992) National Systems of Innovation: Towards a Theory of Innovation and Interactive Learning, Pinter, London

MacNeill, S. \& Chanaron, J.J. (2005) Trends and Drivers of Change in the European Automotive Industry: Mapping the current situation, International Journal of Automotive Technology and Management, Vol. 5, 1, 83-106.

Maxton, G.P. and Wormald, J (2005) Time for a Model Change. Re-Engineering the Global Automotive Industry. Cambridge: Cambridge University Press.

MIA (2009) The Industry: Statistics. Motor Sport Industry Association. Stoneleigh Park, Warwickshire. Available at http://www.the-mia.com/The-Industry

Malmberg, A and Maskell, P. (1997). Towards an explanation of regional specialisation and industry agglomeration. Europe. Planning Studies, 5, 1, pp 25-43

Nelson R.R. (Ed.) (1993) National Innovation Systems: A Comparative Analysis. Oxford University Press, Oxford.

Nelson, R.R. and Rosenberg, N. (1993), "Technical Innovation and National Systems", in Nelson, R.R. (ed.s), National Innovation Systems: A Comparative Analysis. Oxford University Press, Oxford

ONS (Office of National Statistics) (2008/9) Annual Business Inquiry. Newport, UKPavitt, K. (1984). Sectoral patterns of technical change: towards a taxonomy and a theory. Research Policy 13: 343-373.

Pinch, S. and Henry, N. (1999) Discursive aspects of technological innovation: the case of the British motor sport industry. Environment and Planning A, 31(4), 665-682.

Schumpeter, J A. 1943. Capitalism, Socialism and Democracy. London: Henderson and Spalding.

Singh, A. (1977) 'UK Industry and the World Economy: A Case of De-Industrialization', Cambridge Journal of Economics, 1, no. 2 (June), pp113-36

Storper, M. Salais, R. (1997) Worlds of Production: The Action Frameworks of the Economy. Harvard University Press, Cambridge, MA

US Congress, Office of Technology Assessment. 1995. Flat Panel Displays in Perspective. Washington DC: US Government Printing Office.

Womack, J.P., Jones, D.T. \& Roos, D. (1990). The Machine that Changed the World, New York: Rawson Associates

\section{Notes}

i The authors wish to acknowledge the support of the ESRC under award number RES-00022-2478.

ii Although Coffey (2006) is critical of what he terms the 'myth of Japanese efficiency'.

iii Roland Berger Consulting quoted in Automotive News Europe January 2009.

iv Despite widespread use of the term in this way, it should be noted that Womack et al (1990) stress that they do not view lean production in this way, i.e. in terms of cost-cutting . They also present their approach on the basis of a 'radical' or 'revolutionary' transformation to 'lean' away from 'mass'. This suggests a fairly conservative industry from the 1920 s to the 1970s, up until Japanese producers 'arrived'.

${ }^{\vee}$ For example, Cantwell and lammarino (2000), in investigating transnational firms' location of 'technological innovation' in British regions, find results consistent with the hypothesis that the pattern of transnationals' networks for innovation "conforms to a hierarchy of regional centres, and that the pattern of technological specialization of foreign owned affiliates in different regional locations depends upon the position of the region in the locational 
hierarchy". This confirms earlier work by Cantwell and lammarino (1998), which found that transnationals' networks for innovation and location choices across the EU conform to a "geographical hierarchy of centres", where the "technological specialization of foreign-owned affiliates" in different regions also depends on the position of that region in the hierarchy (Cantwell and lammarino, 2000).

vi BERR is The Department for Business, Enterprise and Regulatory Reform. Formerly the Department of Trade and Industry, it was recently renamed as the Department for Business, Innovation and Science (BIS).

vii There is, not surprisingly, a great deal of controversy over reasons for Britain's experiences of post-World War 2 deindustrialisation, which had become evident by the 1970s (see Singh 1977; for a wider and later survey, see Coates 1996). On the specific case of the auto industry, Cowling (1986) suggests a somewhat different approach to the now popular view, which is further developed in Coffey and Thornley (2009).

viii Science Cities are a UK initiative whereby certain cities received resources to develop innovation through large scale initiatives linking business and the science base.

${ }^{\text {ix }}$ Although it should be noted that as of September 2009 no AAP funding had as yet been forthcoming, and Tata turned down the offer of support given the onerous conditions attached.

${ }^{x}$ As well as cumulative learning and incremental innovations, radical technological leaps often emerge from idiosyncratic synergies between sectors or clusters. In this context, in the West Midlands, cluster-to-cluster networking between, for instance, aerospace and services, auto and services, aero and auto, medical technologies and serious gaming, could be critical. Enterprises and policy makers arguably need to work harder to exploit the synergies of cross-cluster working.

${ }^{x i}$ Whilst the connection between green technology and motor sport may not be immediately obvious racing is often a test bed for new vehicle technologies. The 'harshness' of the racing environment exceeds that of normal road use and requires durable and high quality components. In addition, fuel efficiency is a clear priority. Until recently, F1 teams have also been able to spend large amount on $R \& D$ to gain a competitive edge over rivals. That may change with the push towards a cap on spending in future years to try to retain a 'competitive balance' in the sport in an environment of restricted sponsorship revenues.

xii Another interesting case is that of Riversimple LLP, which is developing hydrogen cars in conjunction with the gas producer BOC. Its technological blueprint is open-source, and the enterprise is inviting anyone to develop and add to the technology. 